\title{
Correction to: Gaps in the College Application Gauntlet
}

\author{
Brian Holzman $^{1}$ (D) $\cdot$ Daniel Klasik ${ }^{2} \cdot$ Rachel Baker $^{3}$
}

Received: 1 June 2018 / Published online: 4 October 2019

(c) Springer Nature B.V. 2019

\section{Correction to: Research in Higher Education https://doi.org/10.1007/s11162-019-09566-8}

The original version of this article contain errors. The authors would like to correct the errors as given below:

(a) In Table 4, the word "State characteristics" should read as "State fixed-effects".

(b) In the reference "Berkner, L., \& Chavez, L. (1997). Access to postsecondary education for the 1992 high school graduates NCES 98-105). Washington, DC: UNational Center for Education Statistics, U.S. Department of Education", the word "UNational Center for Education Statistics" should read "National Center for Education Statistics".

The corrected Table 4 and reference are given below.

Reference

Berkner, L., \& Chavez, L. (1997). Access to postsecondary education for the 1992 high school graduates (NCES 98-105). Washington, DC: National Center for Education Statistics, U.S. Department of Education.

The original article has been corrected.

Publisher's Note Springer Nature remains neutral with regard to jurisdictional claims in published maps and institutional affiliations.

The original article can be found online at https://doi.org/10.1007/s11162-019-09566-8.

Brian Holzman

bholzman@rice.edu

1 Department of Sociology and Houston Education Research Consortium, Rice University, 6100 Main Street, Mail Stop 258, Houston, TX 77005, USA

2 Graduate School of Education and Human Development, The George Washington University, 2134 G Street NW, Room 311, Washington, DC 20052, USA

3 School of Education, University of California - Irvine, 2060 Education Building, Mail Code 5500, Irvine, CA 92697, USA 
Table 4 OLS regressions predicting the relationship between race and income gaps in enrollment, admission, and application and race and income gaps in the completion of earlier steps

\begin{tabular}{|c|c|c|c|c|}
\hline & (1) & (2) & (3) & (4) \\
\hline & Enrollment & Enrollment & Admission & Application \\
\hline Grade 9 educational expectations & $0.13(0.10)$ & $0.02(0.16)$ & $-0.11(0.15)$ & $0.02(0.13)$ \\
\hline Grade 11 educational expectations & $0.08(0.14)$ & $0.14(0.16)$ & $0.09(0.14)$ & $0.09(0.13)$ \\
\hline Academic qualifications & $0.09(0.08)$ & $0.53(0.12)^{* * *}$ & $0.53(0.12)^{* * *}$ & $0.40(0.13)^{* * *}$ \\
\hline College search activities & $-0.15(0.10)$ & $-0.05(0.11)$ & $0.14(0.09)$ & $0.10(0.13)$ \\
\hline Took SAT/ACT & $0.32(0.08)^{* * *}$ & $0.53(0.15)^{* *}$ & $0.28(0.11)^{*}$ & $0.24(0.08)^{* * *}$ \\
\hline Selectivity of college application & $-0.19(0.19)$ & & & \\
\hline Selectivity of college admission & $0.93(0.19)^{* * *}$ & & & \\
\hline Filed FAFSA & $0.04(0.10)$ & & & \\
\hline High school graduation & $-0.04(0.05)$ & & & \\
\hline Group fixed-effects & $\times$ & $\times$ & $\times$ & $\times$ \\
\hline State fixed-effects & $\times$ & $\times$ & $\times$ & $\times$ \\
\hline $\mathrm{N}$ & 60 & 60 & 60 & 60 \\
\hline Adjusted $\mathrm{R}^{2}$ & 0.92 & 0.82 & 0.82 & 0.85 \\
\hline
\end{tabular}

Robust standard errors in parentheses

${ }^{+} \mathrm{p}<0.10, * \mathrm{p}<0.05, * * \mathrm{p}<0.01, * * * \mathrm{p}<0.001$ (two-tailed tests) 